УДК [791.634-051(430)Рон:791.11"1929"Вітер]+[791.62:061ВУФКУ]](045)

ORCID ID: 0000-0001-5348-2793

Сгоров Ілля Сергійович,

аспірант кафедри кінознавства. Київський національний університет театру, кіно і телебачення імені І. К. Карпенка-Карого, Київ

Егоров Илья Сергеевич, аспирант кафедры киноведения. Киевский национальный университет театра кино и телевидения имени И. К. Карпенко-Карого, Київ

Illia Yehorov,

Postgraduate Student of the Cinematography Department. Kyiv National I. K. Karpenko-Karyi Theatre, Cinema and Television University, Kyiv

\title{
ТВОРЧИЙ СТИЛЬ ОПЕРАТОРА ЙОЗЕФА РОНИ У КАРТИНІ «ВІТЕР 3 ПОРОГІВ»
}

\begin{abstract}
Анотація. Під час відновлення культурних та освітніх причинно-наслідкових зв'язків важливо пам'ятати про вагомий внесок у розвиток Всеукраїнського фотокіноуправління західних спеціалістів. Становлення відомих імен, таких як, наприклад, Довженко та Демуцький, тісно пов'язане із впливом старших поколінь кінематографістів - тих, що залишилися за обрієм слави своїх учнів. Важливо, що вплив цей був не лише антагоністичним, як прийнято вважати, а й цілком плідним, іноді фундаментальним. У цій статті автор розглядає творчий стиль і роль у становленні української операторської школи німецького кінооператора Йозефа Рони через аналіз однієї з його найвизначніших картин — «Вітер 3 порогів» (1929).
\end{abstract}

Ключові слова: ВУФКУ, українська операторська школа, Йозеф Рона, Данило Демуцький, «Вітер 3 порогів», німецький експресіонізм.

Постановка проблеми та актуальність дослідження. Під час дослідження української операторської школи постає питання щодо недостатньої уваги з боку критики до певних операторів-постановників, які вклали значний творчий та професійно-ремісничий внесок у розвиток кіноіндустрії доби ВУФКУ. Для відновлення історичної справедливості та створення цілісної картини розвитку операторської професії в Україні слід підняти актуальну тему — аналіз творчості цих операторів. Методом дослідження $є$ історично-порівняльний метод і метод персонального аналізу.

Серед недооцінених за впливовістю та значенням українських операторів 20 -х років постають професіонали, запрошені з Німеччини. На рівні з досвідченим Борисом Завелєвим, у молодому ВУФКУ з 1925-го року отримують контракти спеціалісти Йозеф Рона та Альберт Кюн. Через брак власних кваліфікованих кадрів їх запрошують на
Одеську кіностудію за програмою підвищення професійно-технічного рівня фотокіноуправління. Але роль німців не можна зводити лише до розвитку технічно-ремісничого рівня персоналу - оператори Рона, Кюн та декоратори Гайнрік Байзенгерц і Карл Гаакер (Українське Німе, 2011, c. 334) приносять з собою в Україну цілий пласт естетичних поглядів.

Mema cmammi. Новизною цієї статті є операторський аналіз роботи Йозефа Рони у картині «Вітер з порогів», а метою - доведення тези, що Рона був не лише технічним, а й творчим професіоналом і та своїм доробком долучився до формування української операторської школи, зокрема до становлення молодих українських операторів, таких як Данило Демуцький.

Аналіз досліджень і публікацій. «Сама присутність німецьких кінематографістів свідчить про безпосередній вплив німецького театру й кіна 
на українську кінопромисловість двадцятих років» (Госейко, 2005, с. 33). 3 німцями у ВУФКУ прийшов експресіонізм, який перейняла українська кіно-молодь і завдяки якому врешті українська операторська школа отримала нове дихання. Підтвердження цього бачимо у творчих рішеннях та словах видатного оператора Данила Демуцького, у тогочасній («Три оператори» М. Ушакова) та сучасній («Українське кіно: тексти і контекст» О. С. Мусієнко) кінознавчій літературі.

Виклад основного матеріалу. Йозеф Рона (Joseph Rona) — німець австрійського походження, 1878 року народження, дата його смерті невідома. До прибуття в Україну він зняв $з$ десяток картин у Німеччині, у тому числі й у ролі режисера.

Досвідчений Йозеф Рона перший свій фільм в Одесі — «Вася-реформатор» (1926) - зніматиме $з$ Фавстом Лопатинським, де після відсторонення від картини Лопатинського режисерські обов'язки поділять між собою 48-річний запрошений оператор та 30-річний амбітний сценарист Олександр Довженко. Зацікавившись кіно, Довженко написав сатирично-моралізаторський сценарій дитячого фільму, що не відразу був прийнятий у студійну роботу. Постановку «Васі-реформатора» було доручено Фавстові Лопатинському, але згодом Довженкові доручили самому режисирувати картину. «Не володіючи технікою, початківець створює під час зйомок інцидент за інцидентом» (Госейко, 2005, с. 36) - через відсутність досвіду молодий Довженко конфліктує 3 упевненим у своєму професіоналізмі Роною та врешті залишає завершувати стрічку самому німцю. Пройшовши крізь відмови студії та трьох режисерів, комедія виходить провальною й, мабуть, не випадково - втрачається.

Як свідчить біограф Данила Демуцького, його учень Леонід Кохно,

Демуцький знімав цей фільм у співдружності 3 іноземним спеціалістом, оператором Роною, який вважався великим знавцем техніки кіно i менше - художником. Робота Демуцького зводилась до опанування техніки кінозйомки і запозичення операторських прийомів у Рони. Довженко виступив у фільмі більше в ролі сценариста, ніж режисера. Це була його перша проба в галузі кінодраматургії, так само як у Демуцького - в опануванні техніки зйомки. Всю свою увагу художники зосередили на вивченні законів мистецтва кіно, його мови і основ техніки. Картина нічим не виділялась. Митці критично поставились до своєї першої роботи і навіть не визнавали їі за кінотвір. Але довгождана мрія Демуцького здійснилася: він зняв, нехай і не цілком самостійно, перший фільм. (Кохно, 1965, с. 19)

Отже, Кохно низько оцінює постать Рони як художника в кіно i, як буде доведено нижче, робить це несправедливо - адже у картині «Вітер 3 порогів» Рона проявляє такий художній рівень, що його аж ніяк не можна назвати лише «знавцем техніки», він $є$ справжнім художником. При цьому сам Кохно визнає, що Довженко з Демуцьким навчалися кіно на зйомках «Васі-реформатора», а значить у них було в кого навчатися. Хотів він того чи ні, а Рона передав свій досвід та естетику молодим українським кінематографістам.

Переймаючи естетику німецького кінематографа й отримуючи практику співпраці з досвідченим Роною на стрічках «Вася-реформатор» та «Ягідка кохання», Демуцький у наступній своїй картині - «Два дні» (1927) доведе власну самобутність та утвердить свої художні погляди й кінець кінцем стане постійним оператором Олександра Довженка, з яким вони зняли знакові для української операторської школи картини.

Рона у свою чергу, після «Ягідки кохання», працював оператором над нині втраченими картинами - фільмом «Проданий апетит» (1928) за памфлетом Поля Лафарга режисера Ніколая Охлопкова $з$ Амвросієм Бучмою в головній ролі; дитячим фільмом «Шкідник» (1929) Констянтина Болотова; революційною драмою «Митрошка солдат революції» Марка Терещенка; історичному фільмі про фортецю Хаджибей та заснування Одеси «Перлина Семираміди» (1929) Георгія Стабового; кінооповіданням, що збереглося, про будівництво Дніпрогесу режисера Арнольда Кордюма «Вітер 3 порогів» (1929); пролетарською соціальною драмою «Мірабо» (1930) Арнольда Кордюма; драмою «Свій хлопець» (1930) Лазаря Френкеля. Була відновлена також на Київській кіностудії Українфільму (відділ «Техфільм») — після тривалої втрати - українська науково-популярна картина «Людина і мавпа» (1930) режисерів Андрія Вінницького та Юзефа Муріна. Віднайшли iii аж 2017-го року у японському кіноцентрі в Осаці співробітники Довженко-центру.

Не збереглися також режисерсько-операторські роботи німецького кінематографіста - екранізації творів української класики. Серед них «Микола Джеря» (1926) (сценарій Миколи Бажана, за повістю Івана Нечуя-Левицького), «Борислав сміється» (1927) (сценарій Павла Нечеси, за повістю Івана Франка). Також у співрежисерстві 3 Арнольдом Кордюмом Рона зняв «Полум'я гір» 1931-го року. 
«Ягідка кохання" не вирізняється якимось особливим візуальним стилем, проте демонструє чудову виробничу школу. Робота 3 павільйонним світлом у ній досить формальна, хоча й акцентує об'єм простору, бо спрямована на побудову задньо-бокових малюнків і контрового моделюючого світла. Для поглиблення простору в павільйоні та інтер'єрі у кадр вводять дзеркала, які компонуються зі скляними дверима та вікнами у глибині й фактура яких проявляється заднім освітленням.

На натурі Рона з Демуцьким неодноразово будують кадр проти сонця, що виграшно окреслює фігури акторів та відокремлює їх від тла, а також вимальовує на другому плані красиві тіні від крон дерев. На натурних середніх портретах вони використовують дзеркала чи хромовані рефлектори, для того щоб утворити потужні задньо-бокові та бокові підсвітки. Також на натурі оператори часто працюють у геометричній перспективі вулиць i доріг - персонажі бігають по цих дорогах у глибину кадру та навпаки.

Статична та «важка» камера «Ягідки кохання», якій рідко давалося навіть панорамування, у кульмінації фільму починає рухатися - спочатку на трамваї чи то автомобілі, знімаючи згори актора, що їде задом наперед у колясці мотоциклу, потім в епізоді, де головний персонаж чіпляється зовні до трамваю $з$ дитячою коляскою, а далі - у швидкому (та прискореному на монтажі) паралельному проїзді з кінним возом, знятим, вочевидь, 3 відкритого автомобіля. Цікавим чином оператори також використовують рапідну зйомку — після крику героя: «На всіх парах!» — кадр зі стартуючим на камеру конем з возом виявляється уповільненим. У цьому фільмі подібний прийом виглядає дещо недоречно, хоча і можна мотивувати його деяким атракціонним ефектом. Проте такі ж уповільнені величні коні потім вбігатимуть у кадр «Звенигори», а отже сама механіка рапіду, яку Рона показав Довженкові, була випробувана недаремно.

«Bimep з порогів» (1929) режисера Арнольда Кордюма й оператора Йосипа Рона — вже набагато серйозніша та витончена у всіх сенсах робота. За іронією долі чи то через закономірну вузькість і переплетеність національних кінематографічних кіл цей фільм повертає нас до вищезгаданої «Запорозької січі» 1911 року (піонера українського кіно режисера та оператора Данила Сахненка), у якому майбутньому режисерові Кордюму довелось дебютувати як актору. Історія та природа України таким чином вплітається і в символіку та емпірику операторської школи. До того ж сам
Кордюм віддав данину театральному майстрові Миколі Садовському, чия трупа брала участь у зйомках 1911 року, та вже сам як режисер зняв Садовського у його єдиній у житті головній ролі. Окрім того, художником картини знову ж став вищезгаданий художник «Тараса Трясила» та «Звенигори» В. Кричевський.

Фільм починається 3 прекрасних пейзажних кадрів - композиції яких так само сильні та стрімкі, як граніт каменю та потоки Дніпра. У пейзажі та у масових сценах Рона так само, як i Завелєв, досить часто використовує високі точки - вони допомагають йому показати глибину та безкрайність натурного простору - скель, водної гладіні та та похилих берегів.

Високі точки дають змогу охопити композицією більше планів, створити глибинність зображення. Зокрема це проявляється у сценах з групою акторів, які розташовані у глибині кадру, завдяки точці камери, що вища за звичайну висоту очей людини, ми можемо побачити акторів, які розміщуються позаду всіх. Наприклад, у одній зі сцен масового віче селян крупний план героя Садовського знято з рівня трохи вищого за його голову (а зріст актора досить солідний), — таким чином, слова головного героя підносяться до вираження загальної суспільної думки, бо за його спиною (у буквальному та переносному сенсах), що видно завдяки підвищеній точці, стоїть ціле село, у якому він виступає «вищим» авторитетом. Інші кадри спонтанних сільських зборів також насичені високими точками - проїзди на автомобілях, загальні плани, у яких селяни з'їджаються на головну вулицю села — й часто зняті в висоти для поглиблення геометричної перспективи, візуального підсилення численності акторів, а отже і для виразності загальної непромовної думки про глибоку згуртованість селян, їх локальну суспільність, на загрозу та розбрат якої приходить суспільність штучна та химерна, інтернаціонально-комуністична.

Показово, що персонажів пролетарського класу, ідейних і безідейних комсомольців, автори «Вітру с порогів» часто зображають, навпаки, 3 нижнього ракурсу: $з$ одного, пропагандистського боку, це формально звеличує їх (подібно до ракусних фотографій Олександра Родченка), але $з$ іншого, що більш важливо, це їх деперсоніфікує, робить з цих людей великі, але німі та скуті пам'ятники. Показовим у такому подвійному трактуванні $€$ кадр з нижньої точки у повний зріст на помічника геодезиста, який стоїть струнко 3 довгою вертикальною мірною лінійкою, ніби 
міряє не землю, а себе - цей чоловік як явний антипод скіфським бабам, які обрамляють фільм, 3'явився нізвідки та встромив лінійку на чужій землі - він без своєї історії, душі та обличчя, хоч, на відміну від баби, - створений 3 плоті й крові.

А от пейзаж у фільмі, навпаки, має «обличчя〉 - він персоніфікований, ніжний і сильний, облюбований і натхнений художнім поглядом, у фільмі він наділений плоттю та кров'ю. Головна водна артерія України, разом з людьми, які живуть біля неї та поколіннями оспівували ії у піснях, переживає у фільмі свою трагедію. Плоть Дніпра скелі та схили - розривається на шматки. Стрімку кров нові люди хочуть закупорити та розлити довкола. Душа Дніпра - непохитна Скіфська баба - дивиться на це злісне втручання у природу $з$ висоти віків. Можна простежити глибокі алюзії на «Звенигору» Довженка, що з'явилася роком раніше - магічна гора та їі багатовічний дід-хранитель перегукуються зі стихійним Дніпром та його вірним оборонцем дідом-лоцманом 3 «Порогів...».

Йозеф Рона приділяє натурі багато часу та витримки — численні пейзажні локації у фільмі дуже різноманітні, вочевидь знайдені після тривалих пошуків, зняті у різних вдалих ракурсах та у найвигідніший щодо світла та погоди час доби. Через це природа «Вітру з порогів» містить повний спектр настроїв та емоцій, переживає перипетіï, крах і катарсис як окремий персонаж.

Ліричний бік української землі розкритий численними мирними й тихими навколосільськими пейзажами. Тиха вода у ставку, дерева, що схиляють до неї віти, віддзеркалення у воді пейзажу на протилежному березі, виразна тональна перспектива, що проявляється через вибілене сонцем повітря у глибині кадру - у фільмі Кордюма бачимо ледве не цитування сцени випасання ягнят юним Тарасом Шевченком з однойменного фільму Петра Чардиніна. Темний паркан по передньому плану, силуетний стовбур дерева, у глибині кадру - в тональній перспективі озеро зі зграєю білих качок. Водою стелиться туманець, у ній відбиваються дерева на іншому березі. Біловолосий хлопець у білій сорочці грає на білій сопілці, за ним на тлі виграють на сонці легкі хвилі ставка. Деталь жаби. Загальний план з отарою овець по передньому плану. Дуже мальовничо та вдало по боковому сонцю - у «Вітрі з порогів» ця сцена знята більш вишукано та різноманітно, ніж схожа сцена у картині «Тарас Шевченко».

Хорошим прикладом «ліричного» пейзажу $є$ також «нічна» сцена зі злодійством у батьківській хаті, яка стає переломною у сюжетній лінії дочки лоцмана. Сцена починається з вечірнього кадру: на загальному плані бачимо силует дерева та хату з комином на тлі західного неба. Далі йде інтер'єрний візуальний ряд, що знятий зі штучним освітленням. У задньо-боковому світлі з-за дверей деталлю окреслюються ноги злодія, який прокрадається до хати, коли хазяї заснули. Усі його дії нам показують через крупні деталі його рук, ніг та предметів реквізиту, з якими він взаємодіє (злодій показово відрізає половину буханки хазяйського хліба) - обличчя таємного візитера ми так і не побачимо. Кадри в інтер'єрі досить контрастні та експресивні, світло задньо-бокове та бокове, працює всередину через віконні та дверні отвори - виважене й мінімалістичне. Виразним $\epsilon$ кадр згори донизу на підлогу, де біля ніг злодія падає ромб світла з вікна; або ж портрет героїні, яка прокинулась та у чудовому штучному «місячному» світлі дивиться у вікно на втікача, що побіг iз награбованим.

Головний же прийом оператора у цій сцені проявляється коли грабіжник вибігає з будинку — це зйомка «дня під ніч» в екстер'єрі. Боковий малюнок сонячного світла створює потужний контраст, дає кадру багато темних мас; повністю ж затемнює кути кадру та тим самим опускає глядача у 'ніч' щільна чорна віньєтка по периметру зображення. Прийом з віньєткою виглядає досить просто та нехитро, проте у контексті всієї сцени демонтрує високий клас операторської майстерності Йозефа Рони - адже одна й та сама безперервна сцена знімається у різний час та в різних умовах і при цьому на екрані видається цілісною. У сцені поєднуються кадри, зняті при високому денному сонці, з кадрами на заході сонця, кадрами в «павільйонному» ізольованому інтер'єрі, знятими зі штучним освітленням, - проте усі вони асоціюються з одним світлотіньовим ключем; штучність прийомів, яка у них подекуди використана, не химерна, балансує на межі експозиційної необхідності та естетичного мінімалізму.

Закінчується сцена «нічної» втечі знятими у режимному нижньому контровому сонці кадрами на ставку. Силуети дерев, блиск води на сонці, виразна форма човна на тлі хвиль, лілеї на воді, трави на березі - кадри створюють ліричну, казкову, дещо імпресіоністичну атмосферу, а активна дія безликого втікача у кадрі водночас акумулює експресивну напругу. Постать людини стоїть до камери спиною у задньо-боковому світлі, а тінь від неї (чорний бік особистості) виходить на перше місце у кадрі. Так на тлі «непорочного» пей- 
зажу особливо контрастно проявляється «гріхопадіння» людини - цей мотив проходить у різних варіаціях через весь фільм. На наступному загальному плані зловмисник вже пливе на човні, прорізаючи своєю траєкторією вертикальні лінії силуетів дерев по задньому та передньому плану та у віддзеркаленні води - ще один романтичний, витончений художній кадр у виконанні Рони.

Настає ранок, лілії на воді ловлять промінь сонця, що проглядає між деревами. Зрада, перелом у душі, який проживає героїня, візуалізована через схвильоване віддзеркалення у воді ставка. Хвилюються у відображенні води дерева (природа), береться хвилями у відображенні води героїня. Операторська знахідка водночас і мінімалістична, і влучна, змістовна - почуття дівчини, iї сльози та материнська жіноча натура передаються через образ води, архетипний атрибут народження та життя. Водночас вода на обличчі героїні символізує Дніпро - ріку, яку також використали без відповідальності та любові, зрадили й обікрали. Підсвідомо чи умисно автори фільму вклали у нього багато символів.

Лірика пейзажів Рони розкривається також у численних денних сценах. Околиці українського села, ставки, галявини, ліски подано авторами фільму з великою увагою до часу зйомки, світла та виразності ракурсу. Оператор добирає та викристалізовує саме такі кадри, щоб створити напівказковий, ідеалістичний образ життя селян на дніпровських порогах. Врівноважені композиції, вранішнє сонце, що кидає плями на дерева над водою, численні кадри 3 силуетами гілок, дерев та парканчиків по передньому плану, сільські хати 3 верхньої точки, зигзаги доріг у геометричній перспективі. У глибині кадру - активні об'єкти, люди та човни, що пливуть по воді. Скелі нависають над пляжем, вода виблискує у піні, одинокий човен світлою масою стоїть на темній від віддзеркалення дерев воді - гарна робота з контрастом у композиції. Або ж виразний пейзаж заходу сонця - світило на обрії, Дніпро, по передньому плану пліт. Кадр з темними хмарами - наче з градієнтним фільтром.

Загалом образ Дніпра у фільмі більш активний та потужний, ніж образ «ліричного» села. Дніпро уособлює радше чоловіче начало.

Дніпровські пороги, стрімкі течії знімають 3 берега та у русі з води, 3 плотів, човнів чи кораблів. Наприклад, спуск лоцманів порогами - це фактично екстремальні зйомки. Щоб монтаж вийшов різноманітним і динамічним, оператор бере багато різних планів, підбирає різне тло, докладає зусиль, щоб зняти акцентовані деталі хвиль, каміння, колод, тросів, керма, весел, ніг, рук тощо. Він будує неврівноважені динамічні композиції, знімає з верхніх точок. Працює з глибиною та багатоплановістю - наприклад, знімаючи лоцманів на плотах, він бере по передньому плану воду, а по тлу за людьми знаходить гори; або ж будує кадр «вісімку» 3-за плеча діда, який стоїть на передньому плані, а молодик на плоту - у глибині кадру; чи ще один приклад сюжетної-граючої багатоплановості - 3 верхньої точки на надзагальному плані знято, як пліт повільно випливає з-за скелі (слід додати ремарку, що цей кадр, як і багато інших натурних кадрів Рони, схожий за стилістикою до майбутньої роботи Юрія Єкельчика у «Суворому юнаку» - у композиціях цих операторів виникає певна позачасова умовність, сюрреальність). На воді серед ритму деталей також виникає рухома суб'єктивна камера, що гойдається на хвилях.

Взаємодія лоцманів $з$ дніпровськими порогами символізує традиційну та екологічну взаємодію людини 3 природою, на противагу більшовицькій індустріалізації. Ця взаємодія мужня й важка, проте не шкідлива, не загарбницька та не руйнівнівна. I природа у цій взаємодії хоч і створює людям перепони, проте, роблячи їх сильнішими, піддається та сама залишається незмінною. Це явище сильно контрастує з тим, як автори демонструють будівництво Дніпрогес.

Настільки візуально виразні, ніби аж озвучені, у фільмі з'являються численні вибухи динаміту, закладеного у гірські породи навколо Дніпра. Вивірені загальні плани, знайдені вдалі ракурси, обчислені перед вибухом розміри пилових та димових «грибів», дають змогу Роні зняти якісний і нетривіальний документальний матеріал. Клуби пилу та уламків, увесь кадр у хмарах; вибухає скеля над водою - i хмара пилу та брили каміння летять у воду в бік камери, на тлі - пагорби дальніх берегів.

Динаміка вибухів у монтажі перероджується у динаміку скачки на конях - так само, як у «Ягідці кохання», проте вже не у місті, а по лісових галявинах та стежках, - Рона фільмує акторів, які женуться запряженими кіньми візками 3 візка чи автомобіля, що їде паралельно. Швидкість акцентовано тим, що між ігровим та знімальним транспортом «проносяться» дерева; так само рух дерев відбувається на задньому плані. Динамічна сцена знята у різних крупностях - на загальному та середньому з операторського транспорту, та на крупних - 3 камерою, розміщеною вже на ігровому візку. Знову бачимо суб'єктивну 
камеру - напружений погляд героя спрямовано на ліс, що летить повз (на жаль, у цьому кадрі автори не зберегли вісі погляду актора та камери). Вибух у силуеті, вибухи у різних ракурсах. Ця сцена - загалом одна $з$ найметафізичніших. На портрет героя, який переживає переусвідомлення, напливають кадри 3 будівництва — вони пролітають повз погляд його уяви панорамами, змазаними у моушн-блюрі паралельними проїздами та швидкими перекиданнями, наче марення. Кадри дерев і ланів, що миготять повз візок, перепливають у кадри химерних конструкцій Дніпрогесу. Кадр з вибухом скель монтується поряд 3 кадром тихого ставка у селі - по передньому плану збоку кадру дерево, в центрі композиції силуетний очерет, що мальовничо віддзеркалюється у воді, в глибині кадру - дахи мазанок. Разом 3 молодим персонажем глядач проживає руйнацію та перевтілення природи порогів, бачить контраст між тихою мальовничою природою та гуркітливим динамітно-металевим антропоморфним втручанням у неї.

Але позиція авторів фільму неоднозначна вони водночас і засуджують, і оспівують велике будівництво - ніби обережно подають його наслідки на розсуд глядачеві. Рона вправно знімає не лише ставки на сході сонця та стрімку річку 3 води, а й документальні спостереження за будівництвом. Крани зняті знизу вгору, силуети їх металевих скелетів; завалені під 45 градусів композиції, що перехрещуються, - конструкції, будинки, стовпи; використання напливів; зйомка 3 рухомої башти крана; різні крупності, ракурси, вдалі фази, вправні панорами - палітра прийомів досвідченого німецького оператора досить велика, а його погляд не менш гострий за «око» братів Кауфманів.

Скрізь, де це можливо, навіть у документальних кадрах, Рона шукає глибинну композицію наприклад, кадр знятий з точки трохи вищої за висоту вантажного вагона, у який ковш крана скидає валуни, демонструє геометричну перспективу залізниці, яка робить поворот і за якою у самісінькій глибині - річка та гори, показує тональну перспективу за рахунок клубів пилу. Фігури акторів також зіставлені з тлом, за рахунок довгого фокусу та розмиття тла портретні кадри наповнені глибиною. Герої поринають у атмосферу навколишньої дії, а не вибиваються з неї. У робочому процесі оператор також знаходить ліричні настрої - наприклад, у кадрі, де двоє робітників щось силуетно кують. Суб'єктивну камеру бачимо також у сцені з краном — актор дивиться вгору та повертає голову — i потім його погляд, що проводжає кран, імітує камера.

На будівництві, як і в ігрових частинах фільму, Рона також широко використовує деталі динаміт, дзвін, каміння, ковші тощо. До деталей у Рони особлива увага - він чудово розуміє, що саме в них полягає одна з відмінностей кіно від театру та, відповідно, один $з$ сильних драматургійних інструментів. На деталях зняті сцени злочинної, детективної дії - вищеописаної крадіжки хліба вночі з хати, сцени таємного нічного відрубування дідом плота від приколу. У фильмі також багато деталей тварин - качки, гавкаючі собаки, свині, жаба, вівці, кукурікаючий півень тощо це доповнює образ природи у кадрі, акцентує увагу на гармонійному співіснуванні селян з фауною. Є також деталь колеса авто, що застрягло у багнюці, — вона підсилює складність ситуації, у яку потрапляють персонажі.

Як і в «Ягідці кохання», у «Вітрі з порогів» Рона широко використовує зйомку у русі на авто. Окрім кульмінаційної метаморфози персонажа, що їі ми описували вище, рух на авто зустрічається у різних сценах і варіаціях. Рона веде машину «у лоб», коли ігровий транспорт прямує за операторским; використовує різні крупності у паралельному проїзді; знімає крупні плани вже з ігрового транспорту; знімає суб'єктивний погляд героя 3 руху. Крім того, з машинами та кінними повозами у кадрі оператор будує тональну та геометричну багатоплановість — як і в багатьох попередніх фільмах ВУФКУ це відбувається завдяки густим білим вихлопним газам та клубам пилу з-під коліс. Рона також декілька разів знімає рух авто на камеру з глибини дороги - це поєднує в одному кадрі геометричну й тональну перспективу, додає композиційної динаміки через діагональну композицію зигзагоподібних заворотів дороги. Подібну сільську дорожну глибину, утворену пилом та геометрією, побачимо у танці Івана $з$ довженківської «Землі».

Працюючи 3 денними акторськими сценами на натурі, Рона обирає бокове та задньо-бокове сонце, а тіньовий бік часто відпрацьовує активними підсвітками. Денні інтер'єри у Рони не завжди вдалі - майже лобова підсвітка заливає акторів і декорацію, руйнуючи тривимірність простору. В нічних же та вечірніх інтер'єрах він активно використовує бокові та задньо-бокові джерела, що «працюють» 3 віконних та дверних отворів, і це дає зображенню виразний контраст і драматизм. Досить вдало оператор імітує ефект освітлення від мерехтливого вогню у пічці. 
3 першого до останнього кадру фільму пересвідчуємось, що німець Рона нічим не гірше за Демуцького, Завелєва, Кауфмана чи Tiсcе вловлює деталі української натури. Окрім того, нарівні $з$ вищенаведеними операторами Рона чудово орієнтується як в ігровому, так і в документальному середовищі. Він уміє знаходити сміливі різкі ракурси: взяти до прикладу кадр знятий 3-під лопатей вітряка - дерев'яні конструкції крутяться та летять на камеру у небезпечній близькості біля неї. У цьому кадрі $є$ кауфманівська сміливість і композиційна винахідливість - образ вітряка як образ гомону людей, які розносять новину про руйнування порогів), та при цьому оператор має терпіння довго перебирати пейзажні локації, медитативно вичікуючи, коли на них з'явиться вдале світло. I, звісно ж, як досвідчений оператор та за сумісництвом режисер власних картин, він чудово розуміється на монтажі й драматургії, знімає так, щоб на монтажному столі можна було зібрати динамічні, напружені, різнопланові епізоди.

Якоюсь мірою герой Садовського, на якого наприкінці фільму напливають другою експозицією техногенні ковші та вибухи і який, будучи досвідченим лоцманом, змушений залишити при собі свої уявлення про світ та, передавши весь свій досвід, відпустити молоде покоління у вільне плавання, перегукується з особистістю і Завелєва, і Рони, і Кюна, й інших недооцінених «дідуганів» української операторської школи. Але хоч куди б дід зникав, роботи його учнів чітко показують зв'язок поколінь - недаремно кам'яні баби ще стоять біля Дніпра.

Висновки. Як бачимо, своєю роботою оператор австрійського походження зробив вагомий естетичний і технічний внесок у розвиток укра- їнської кінематографії доби ВУФКУ, прямо чи опосередковано допоміг стати на ноги недосвідченим на той момент талантам - Довженкові та Демуцькому.

Йозеф Рона зник з України на початку 1930x років, коли почалися сталінські «чистки». Подальша його кар'єра, як і доля, на жаль, не відомі. Публікацій його авторства також немає у відомих джерелах, а багато його фільмів вважаються втраченими. Тому, безумовно, біографія Йозефа Рони та його творчий стиль потребують подальшого дослідження й висвітлення, а операторський аналіз його фільмографії завжди буде актуальним для заповнення білих плям та встановлення більш точних причинно-наслідкових зв'язків у історії кінопроцесу Україні 20-х років та розвиткові української операторської школи зокрема.

\section{Бібліографія}

Брюховецька Л., Госейко Л., Касім В., Козленко І., Мензелевський С., Радинський О., Тримбач С.. (2011). Украӥнське німе. Біографічний каталог. Київ: Національний центр Олександра Довженка. 360 с.

Госейко, Л. (2005). Історія украӥнського кінематографа (1896-1995); пер. 3 фр. С. Довгалюк, ред. В. Войтенко. Київ: КІNО-КОЛО. 461 с.

Кохно, Л. (1965). Данило Порфирович Демуцький. Київ: Мистецтво. $64 \mathrm{c}$.

\section{References}

Briukhovetska, L., Hosejko, L., Kasim, V., Kozlenko, I., Menzelevsky, S., Radynsky O. \& Trymbach, S. (2011). Ukrainske nime. Biohrafichnyi kataloh [Ukrainian Re-vision]. Kyiv: Dovzhenko Centre. 360 s. [in Ukrainian]

Hosejko, L. (2005). Istoriia ukrainskoho kinematohrafa (18961995) [History of Ukrainian cinema (1896-1995)]. Kyiv: KINO-KOLO. 461 s. [in Ukrainian]

Kohno, L. (1965) Danylo Porfyrovych Demutskyi [Danylo Demutskyi]. Kyiv: Mystetstvo. 64 s. [in Ukrainian]

\section{Illia Yehorov}

\section{Operator Iozef Rona and his creative style in a picture «Wind from thresholds»}

Abstract. During the restoration of cultural and educational causal ties, it is important to remember the significant contribution of Western specialists to the development of the All-Ukrainian Photo and Film Administration. The formation of famous names, such as, for example, Dovzhenko and Demutsky, is closely connected with the influence of the older generations of cinematographers - those who remained beyond the horizon of fame of their students. It is important that their influence was not only antagonistic, as is commonly believed, but also quite useful, sometimes fundamental. In this article the author considers the creative style and role in the formation of the Ukrainian cinematography school of german cinematographer Josef Rona through the analysis of one of his key paintings — «Wind from the Thresholds» (1929).

Keywords: VUFKU, Ukrainian school of cinematography, Josef Rona, Daniil Demutsky, «Wind from the Thresholds», German Expressionism. 


\section{Сгоров Илья Сергеевич}

Творческий стиль оператора Йозефа Роны в картине «Ветер с порогов»

Аннотация. Во время восстановления культурных и образовательных причинно-следственных связей важно помнить про весомый вклад в развитие Всеукраїнского фотокиноуправліния западных специалистов. Становление известных имен, таких как, например, Довженко и Демуцкий, тесно связано с влиянием старших поколений кинематографистов — тех, что остались за горизонтом славы своих учеников. Важно, что влияние их было не только антагонистическим, как принято считать, но и вполне плодотворным, иногда фундаментальным. В данной статье автор рассматривает творческий стиль и роль в становлении украинской операторской школы немецкого кинооператора Йозефа Рона через анализ одной из его ключевых картин — «Ветер с порогов» (1929).

Ключевые слова: ВУФКУ, украинская операторская школа, Йозеф Рона, Даниил Демуцкий, «Ветер с порогов», немецкий экспрессионизм. 